$$
\begin{array}{ll}
\text { Research Square } & \begin{array}{l}
\text { Preprints are preliminary reports that have not undergone peer review. } \\
\text { They should not be considered conclusive, used to inform clinical practice, } \\
\text { or referenced by the media as validated information. }
\end{array}
\end{array}
$$

\title{
Aloe Vera Protects Fluoride Induced Teratogenic Effects During Pre- and Postnatal Development in Mice
}

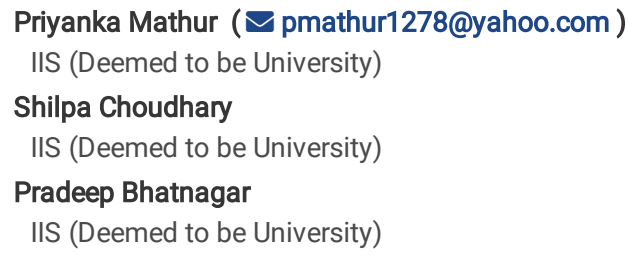

\section{Research Article}

Keywords: Sodium fluoride, Teratogenicity, Aloe-vera, amelioration, skeletal deformities

Posted Date: July 23rd, 2021

DOI: https://doi.org/10.21203/rs.3.rs-635740/v1

License: () (1) This work is licensed under a Creative Commons Attribution 4.0 International License. Read Full License 


\section{Abstract}

Pregnancy and feto-gestational toxicities on exposure to fluoride $(F)$ and its possible amelioration on co-administration with Aloe-vera were studied in pregnant Swiss albino mice. Once the confirmed pregnancy was tested, animals were equally divided into four groups and were given following treatment. Group I was given no treatment and served as Control, Group II and III were administered sodium fluoride, 100 and 300 ppm respectively while group IV was co-administered with sodium fluoride, $300 \mathrm{ppm}$ and Aloe-vera $(300 \mathrm{mg} / \mathrm{kg})$ daily for 14 days prior to gestation and continued till the $18^{\text {th }}$ day of gestation. Animals were sacrificed 'on the $19^{\text {th }}$ day of gestation for prenatal observations. Maternal body weight, the gravid uterine weight, number of corpora lutea in both the ovaries, number of implantations and resorptions, number of live (mature and immature ) male and female fetuses as well as number of dead fetuses were examined in each dam. The treatment continued in another set of animals till the completion of weaning period to observe postnatal changes due to test substances on the mother and pups. Sodium fluoride treated animals showed morphometric and skeletal changes which were more pronounced in the high dose group showing significantly decreased body weight gain in pregnant mothers; and dead/immature fetuses. Morphometric changes included open eyelids, limb defects, wrinkles on whole body, anophthalmias, pulmonary edema, enlarged esophagus and decreased body weight of fetuses and pups. Alizarin prepared skeletal structures of fetuses of such female mice showed delayed ossification or bending in number of bones of skull, thoracic and limb regions. However, concomitant exposure to Sodium Fluoride and Aloe-vera treated animals, there was a marked improvement in all the prenatal and postnatal variables. The study suggests that Sodium fluoride at the high concentrations may be teratogenic while co-administration of Aloe-vera during fluoride exposure might be beneficial in reducing these toxic effects. We thus recommend use of aloe vera as preventive agent or as a complimentary agent during fluoride treatment.

\section{Introduction}

High Fluoride concentration in groundwater is a common problem in number of countries globally and also a serious environmental health issue in India and in particularly the state of Rajasthan, India (Perumal et al., 2013). Increased fluoride concentration in soil and water is known to cause wide array of toxic effects and health issues in human and most common among them are tooth defects, skeletal and visceral malformations, brain injury etc. (Jing et.al, 2004). Fluoride induced teratogenic effects are less studied. Developing animals are more susceptible to fluoride as it crosses the placental barriers and enter the fetus causing malformations. Fluoride concentration has been reported in saliva, sweat and milk though, tough at low concentration (Narayanaswami and Basha, 2010).

Infant mortality due to congenital malformation is now ranked second most important cause of death in developing countries. (Madu, 2015). A common teratogen is known to increases the incidence of structural and/or functional abnormalities in offspring, if consumed in higher concentration by parents before conception, the female during its pregnancy period or if it directly reaches the developing organism through exposure. Various stages of the development of the fetus are also a key factor that determine the susceptibility to teratogenic agent because a specific damage occurs readily during the organogenesis phase of embryonic development. (Inamdar et al., 2012).

Antioxidants and chelators are commonly used in minimizing fluoride induced toxic effects and/or stress, besides documenting the function of minerals and vitamins specifically A, D, C, E against fluoride toxicity (Dharani et al., 2011). Herbal or Plant extracts including their constituents have recently been reported to be of immense benefit as preventive agents, or being used as complimentary or as adjuvant in reducing metal induced toxic effects. With minimal side effects, the medicinal value of these extracts have assumed an important dimension in the past few decades owing largely due to being a rich source of antioxidants that combat oxidative stress through their redox active secondary metabolites and the rising concerns about the side effects of synthetic drugs (Flora et al., 2013). These studies have led researchers to screen number of plants and their extracts for their possible antioxidant properties and also to bind fluoride. With high concentration of fluoride reported in groundwater in various regions worldwide, it is considered useful to explore to explore their potential to combat toxicity of fluoride.

Aloe vera, a succulent plant and a native of arid places like Rajasthan in India with its thick, fleshy, serrated, lanceolate-shaped leaves of green-greyish color belonging to family Asphodelaceae was selected to determine its ameliorative effect against fluoride induced teratogenicity. Its inner gel used in the present study was collected from the lower leaves of the plant by slicing the leaf open. It is a clear, odorless and tasteless and has been used in traditional and folk medicines for thousands of years to treat and cure variety of diseases because vitamins, minerals, enzymes, polysaccharides, phenolic compounds and organic acids are found in abundance in it. (Nada et al., 2013) Studies have reported that Aloe vera gel possess diverse pharmacological and therapeutic activities viz. anti-inflammatory, antibacterial, antioxidant, hypoglycemic and hypolipidemic etc. The gel has also been found to be useful to neutralize free radicals for maintaining the integrity of the antioxidant status. (Eshun and He, 2004). Acemannan, an acetylated glucomannan that makes up the major active component of the mucilaginous Aloe vera gel has great impact on bone formation, influencing the osteoblast and osteoclast activities in the developing and wound healing stages. (Godoy et al., 2018). Besides this, it has phytoestrogen components such as beta Sitosterol that can support normal development of fetus (Atik et al., 2019).

\section{Materials And Method}

\section{Animals}

Adult parous female Swiss albino mice weighing between 25-30 grams were first acclimatized in the animal house of the University (registered with CPCSEA with registration number \#1689/PO/Re/S/13/CPCSEA) at controlled temperature and humidity. All animals were provided standard food pellets and water ad libitum. The experiments were carried out in accordance with the guidelines of the Institutional Animal Ethical Committee (IAEC).

\section{Test chemical}


The test substance Sodium Fluoride (HiMedia Laboratories Pvt. Ltd.) was used after making a solution in normal potable water (Fluoride content in the water was in the range of $1-2 \mathrm{ppm})$.

\section{Plant}

Mature, healthy and fresh leaves of Aloe-vera were washed with fresh water, cut transversely into pieces and thick epidermis was selectively removed. The solid gel in the center of the leaf was taken after homogenizing the leaves (Madhusudhan et al., 2009). The water extract of Aloe-vera gel was prepared mechanically and kept in a clean and air-tight bottle. Each time a dose was prepared by taking $0.7 \mathrm{~g}$ of leaf gel in $10 \mathrm{ml}$ water, which was properly ground.

\section{Teratological evaluation}

Mice were used for studying the teratogenic and anti- teratogenic evaluation. They were divided into 4 groups of 8 mice in each and kept in an air-conditioned room with $12 \mathrm{~h}$ of daylight and $12 \mathrm{~h}$ of night. Estrous cycle was monitored for all animals before mating. Two females with one male animal per cage were kept overnight. Next day, in the early hours, the females were examined for signs of mating by flushing the vagina with saline using a pipette, and then examining the obtained solution microscopically. Mating was confirmed by the presence of sperm cell/plugs. The presence of spermatozoa was recorded as day zero of pregnancy, daily increase in weight further confirmed pregnancy (Hussein and Mahmoud, 2013).

\section{Experimental design}

Animals were randomly divided into four groups with 8 pregnant mice in control group and 24 pregnant mice in treatment groups. Group 1 was given no treatment and served as Control; Group 2 was administered a dose of 100 ppm NaF; Group 3 was administered 300 ppm NaF while, Group 4 was administered 300 ppm Sodium fluoride along-with Aloe-vera. Doses were selected based on its concentration present in many polluted areas and what has been reported in the literature. Doses were given through drinking water ad libitum from 14 days prior to mating and continued till $18^{\text {th }}$ day of gestation.

Postpartum procedure - The animals were autopsied one day after the completion of dose. Following laparotomy, the uterus was exteriorized and the number and location of fetuses, resorption, live and dead fetuses and number of corpora lutea in each ovary were noted, then their weight and length were measured. Living fetuses were distinguished from the dead by reflex movement initiated by gently touching the fetus. Live fetuses were weighed and examined by a hand lens, to observe any malformations. Individual fetuses were examined carefully for external anomalies, then $50 \%$ fetuses were examined for skeletal malformation; rest $50 \%$ fetuses were kept in Bouin's solution for soft tissue examination.

Data analysis - Statistical analysis was performed on parametric values. The values have been expressed as Standard Error of mean (S.E). Maternal weight gain, fetal weight, fetal length and neonatal weights was analyzed statistically using student's t-test.

\section{Results And Observations}

\section{Maternal toxicity}

$20 \%$ mortality was observed during the treatment with $300 \mathrm{ppm}$ dose of Sodium fluoride. The general body weight gain in mother during the three phases viz: 14 days prior to mating, gestation and lactation periods was significantly reduced at $300 \mathrm{ppm}$ of Sodium fluoride relative to controls; while the maternal body weight in Sodium fluoride+ Aloe vera group increased in all three phases compared to 300 ppm Sodium fluoride exposed group . No mortality was observed in any of the females in this group. Water and food consumption decreased significantly in the animals exposed to 300 ppm Sodium fluoride.

\section{Fetal toxicity}

The prenatal teratological observations in were recorded after performing autopsy on $19^{\text {th }}$ day of gestation. The first parameter which was assessed was the number of corpora lutea counts in animal under study. The average number of corpora lutea in all the animals were found to be insignificantly different from the values recorded in control. In total 77 live fetuses were observed from all the eight animals in the control group; the number of fetuses obtained from all the eight animals in animals exposed to $100 \mathrm{ppm} \mathrm{NaF}$ were reduced (non-significant) compared to the number noted in control group. The value were significantly decreased to 53 in 300 ppm NaF exposed group indicating significant toxic effects during the developmental phase of the animals. The increase in litter size in $\mathrm{NaF}(100 \mathrm{ppm})$ + Aloe vera group was close to litter size in control indicating positive effects of Aloe vera co-administration. Table 1 indicates significant toxic effects of 300 ppm NaF where out of 67 implantation sites, only 53 live fetuses were counted but this included 45 mature fetuses while 8 fetuses were found to be immature (Figure I) (Eii); Number of resorptions and dead fetuses were high in this group of animals. Aloe vera, in view of reported antioxidant effects and other medicinal properties provided significant protective value which were evident from the elevated number of mature fetuses as 65 with just 2 immature fetuses out of the total 67 live fetuses. The resorptions and other parameters were also not significantly on the higher side. The average fetal body weight was recorded at $1.162 \pm 0.045 \mathrm{~g}$ in control, which was significantly decreased in the $300 \mathrm{ppm} \mathrm{NaF}(0.716 \pm 0.054)$. In the other experimental groups there was no significant decrease in average fetal body weight and the average placental weight compared to control.

Normal morphometric development could be seen in the fetuses of control group. Sodium fluoride (HD) group fetuses showed anomalies like open eyelids, wrinkles on whole body (Figure 1- D ), limb defects (Figure 1- B , C ) and stunted fetus (Figure 1 E ii). Body weight got drastically decreased in NaF(HD) group as compared to control group and a low dose group; whereas Aloe-vera group in combination with $\mathrm{NaF}(\mathrm{HD})$ showed no specific morphometric changes and no significant decrease in body weight compared to control.

When $50 \%$ fetuses of each female were sectioned through head, thorax and abdomen; the sections showed normal structure of various organs in the control group However, in 300 ppm NaF exposed group, sections in soft tissue depicted anophthalmias, pulmonary edema (enlarged air spaces in lungs) and enlarged esophagus (Figure 2). Structures seemed normal in female fetus which were co-administered Aloe vera with $\mathrm{NaF}$.

Page $3 / 9$ 
The alizarin staining in remaining $50 \%$ of the fetus which were processed to observe defects of the skeletal system indicates normal ossification in the skull bones of the control group. The ribs, Sterne brae, vertebrae and limb bones did not show any malformations, the observations were similar in the Aloe vera treated group. Sodium fluoride (300 ppm) fetuses showed Craniofacial disorganization, reduced ossification in skull bones, and widened cranial sutures (Figure 3). The rib defects like wide gaps between ribs, and absence of ribs were not found in low dose of NaF group, whereas in the treated group of NaF (300 ppm) a significant number of fetuses had skeletal abnormalities. In this group highly reduced skull ossification, widened cranial sutures, ribs defects like partially ossified ribs, wide gap between ribs, wavy ribs, and reduced Sterne brae, partial ossification of metacarpals (Mc) and metatarsals (Mt), absence of 13th rib were clearly observed (Figure 4).

The postnatal observations of each mother and pups was recorded following parturition till 21 days of weaning period.

Table 2 shows consistently decreased in the average number of alive pups in $\mathrm{NaF}(\mathrm{HD})$ treated group from day 1 through 21 days of weaning period compared to control. (Control $8.40 \pm 0.51$ on day 1 and $7.60 \pm 0.24$ on day $21, \mathrm{NaF}$ (300 ppm) $-7.00 \pm 0.45$ on day 1 and $3.60 \pm 0.51 * \star *$ on day 21 ) while in $\mathrm{NaF}(100 \mathrm{ppm})$ and $\mathrm{NaF}(300 \mathrm{ppm})+$ Aloe-vera group there was insignificant difference in number of alive pups compared to control. The trend was the same in viability index and weaning index also. Average pup weight which is also expressed as Growth index was calculated for different postnatal days findings. It was not much affected in $\mathrm{NaF}(300 \mathrm{ppm})$ and $\mathrm{NaF}(300 \mathrm{ppm})+$ Aloe-vera, compared to control but in $\mathrm{NaF}$ (300 ppm) it got significantly affected.

\section{Discussion}

Epidemiological studies conducted in the areas with high levels of naturally fluoridated water shows increase in birth defects placing fluoride into the same category as toxic metals like lead, mercury, methyl mercury etc. (Guth et al., 2020). Exposure to high fluoride concentration in drinking water during in utero development may result in skeletal fluorosis which becomes evident in childhood. Adverse effects on reproduction have been reported in animals exposed to $100 \mathrm{ppm}$ or greater concentrations of fluoride in their diet or through drinking water. Number of previously reported animal studies suggest that exposure to low concentrations of fluoride do not result in impaired fertility and reproductive capabilities. The present study is an effort to give reason to and correlate the findings obtained through experiments with the various mechanisms by which Sodium fluoride reaches the tissues of the body and influences the normal physiological function of the body; thereby causing developmental defects during the pregnancy period. The study also attempts to find the possible reason / mechanism for averting the teratogenic effect of fluoride by using Aloe vera gel which is taken as a supplement during the early development of a fetus

It has been reported that Sodium fluoride and other Soluble fluorides in groundwater are absorbed from the gastrointestinal tract into the blood (Barbier et al. 2010; EFSA 2005), attaining the peak plasma levels within 20-60 min after oral ingestion (EFSA2005; Whitford et al. 2008). Fluorides is also able to cross biological membranes by diffusion as the non-ionic hydrogen fluoride (HF) (Gutknecht and Walter 1981) and remains retained in tissues for a significant period of time. The largest amount of absorbed fluoride is retained in bone and teeth, where about $99 \%$ of the total fluoride is detected (Ekstrand et al. 1977). Animal studies have reported that fluoride crosses the placenta and gets incorporated in fetal issues; increasing its concentration in fetal blood two folds. Fetus is not protected against fluoride that circulates in the maternal blood. The study further reports that fluoride gets transferred to the infant through mother's milk. Thus, the fetus and new born pups are much vulnerable to fluoride (Caldera et al. 1988; Shen and Taves1974). The skeletal deformities and other morphometric changes observed in the present study can be explained on the basis of such above mentioned findings (Guth et al., 2020). Not only this, fluoride also interacts with proteins, particularly enzymes, and usually inhibits/ stimulates enzyme activity at the concentrations in the millimolar range (Barbier et al. 2010; Mendoza-Schulz et al. 2009) thereby disrupting normal physiology of the body. Fluoride hampers cell functions through generation of superoxide anions (Garcia- Montalvo et al.2009; Izquierdo-Vega et al. 2008); mitochondrial toxicity, e.g., opening of the transition pore (Anuradha et al. 2001); release of cytochrome $\mathrm{c}$ from mitochondria and induction of apoptosis (Chlubek et al. 2003; Lee et al. 2008).

The previous study also suggest that by interfering with calcium metabolism and enzyme mechanisms, fluorides act as direct cell poisons (Guth et al., 2020). It has also been reported that Fluoride interacts with hydrochloric acid in the stomach to form a powerful corrosive hydrofluoric acid. Fluoride ions also combine with serum cations after absorption, especially calcium and magnesium leading to hypocalcaemia and hypomagnesaemia. (Narayanswami et al., 2010). Bones are more susceptible to its effect primarily because fluoride replaces hydroxides and itself gets deposited in bones. The chronic effects of which are called Fluorosis of the skeleton. These findings can be correlated with the finding of Brittany et al., 2014, in which people have developed bone related problems, in those geographical areas where Fluoride concentration is high. The high accumulation of NaF in brain tissues after passing through placenta and mother's milk to its newborns has also been reported (Sun et al., 2018) affecting the prenatal and postnatal development of mice. These effects were more significant following exposure to a high concentration of 300ppm of NaF causing teratogenic effects which got reduced by taking nutritive plant products like Quinoa during the whole experimental period (Choudhary and Mathur, 2020). Several authors reviewed a dose dependent relationship between NaF exposure and embryonic growth retardation in mice and have suggested protective effects of vitamins and antioxidants to ameliorate these teratogenic effects besides cautioning against excessive intake of Fluoride in the drinking water.

Acemannan, an acetylated glucomannan that makes up the major active component of the mucilaginous Aloe vera possess multifunctional properties and therefore acts as a bioactive molecule, exerting an immunostimulatory effect by activating macrophages, (Callaghan et al., 2012) and possessing wound healing actions. (Osefo et al., 2009, Hull and Beale, 1985). It also stimulates fibroblast proliferation, (Lee et al., 2017) tissue regeneration (Rauws et al, 1990) and bone marrow stromal cell proliferation and differentiation in vitro. (Hull and Beale, 1985). Thus, it is an interesting preventive agent for tissue repair. Aloe vera sap has also been found to have favorable effects on estrogen synthesis due to its phytoestrogen components such as beta sitosterol that can increase the estrogen level, thus bringing hormones to support normal development of fetus (Atik et al., 2019). More detailed studies are required to validate and explain the action mechanism of acemannan in bone building. .

It is also an established fact that nutritional supplements such as vitamins and antioxidants prevent the toxicity that is induced by fluoride because these supplements reduce the oxidative stress, decreases the lipid peroxidation, and augments the activity of antioxidant enzymes. (Elshama et al., 2018). One of 
the strategies to protect the body from oxidative injury and to prevent from many disorders is to increase the levels of antioxidant enzymes by increasing the dietary intake of supplements rich in antioxidant enzymes (Godoy et al., 2018). Aloe vera has very strong antioxidant nutrients. Glutathione peroxide activity, superoxide dismutase enzymes, and a phenolic antioxidant have been reported to be present in Aloe vera gel, which may be responsible for these antioxidant effects (Atik et al, 2019). Aloe vera also has unique ability to improve the absorption of natural antioxidants like vitamin $\mathrm{C}$ and vitamin $\mathrm{E}$ that in turn enhances antioxidant status to alleviate fluoride induced ROS (Vinson et al., 2005).Vitamin E which is an essential component of Aloe vera must have exerted antioxidant effects by scavenging lipid peroxyl radicals that are free radicals in vivo as well as in vitro (Niki, 2014). Ayurveda also mentions that Aloe-vera can been taken as a Naimittika Rasayanas during pregnancy; because, it being rich in nutritional contents and iron supplements that are very essential to promote the health of the pregnant women and facilitates full growth and development of progeny in the womb (Shastry,1999; Singh, 2000).

The findings in the present study suggest the multifaceted qualities of Aloe vera. The present study also suggests marked efficacy of Aloe vera in reducing fluoride induced teratogenic effects. However, still more detailed studies are required using variable doses of Aloe vera post flouride exposure

\section{Conclusion}

The present study suggest that pregnant mice exposed to Sodium fluoride may be at the risk of congenital malformations. Aloe vera, a promising herbal product with its various clinical applications in medicine could be useful if co-administered during fluoride to minimize fluoride induced toxic effects including teratogenicity.

\section{Declarations}

Ethics approval: Institutional Ethics committee gave its approval to work on the given experimental model (vide SI 2-18-5-18).

\section{Consent to Participate:}

Authors have given consent to participate in the given research work

\section{Consent to publish:}

Authors have given consent to publish the work which includes figures and tables in between the text in the journal.

\section{Conflict of interest}

The authors declare that there is no conflict of interest related to this study.

Availability of data and materials : Not applicable

\section{Author's funding}

The author(s) received no specific funding for this work.

\section{Authors' contribution}

PM conceptualized the experimental plan, supervised the experiment, prepared the first draft of the manuscript and the main author., SC performed the experiment, collected data and

analyzed. PB prepared the final draft, participated in the discussion during the experiment, and overall supervision of the experiments.

\section{Acknowledgment}

Authors are grateful to the IIS University, Jaipur for providing all necessary laboratory equipments, chemicals and other infrastructural support to conduct the experiments and allowed to work in Department of Scientific and Industrial Research (DSIR), Government of India approved R and D Laboratory (Life Sciences) of the University.

\section{References}

1. Anuradha CD, Kanno S, Hirano S (2001) Oxidative damage to mitochondria is a preliminary step to caspase-3 activation in fluoride-induced apoptosis in HL-60 cells. Free Rad Biol Med31(3), 367-373.

2. Atik, N., Nandika, A., Cyntia Dewi, P. I. and Avriyanti, E. (2019). Molecular mechanism of Aloe barbadensis Miller as a potential Herbal Medicine. Systematic Reviews in Pharmacy, 10(1), 118- 125.

3. Barbier, O, Arreola-Mendoza, L, Del Razo, LM (2010). Molecular mechanisms of fluoride toxicity. Chem Biol Interact,188(2), 319-333.

4. Brittany, L., Poulev, A., Kuhn, P., Mary, Grace, H., Lila, M. and Raskin, I. (2014). Quinoa seeds leach phytoecdysteroids and other compounds with antidiabetic properties. Food chemistry,15(163), 178-185.

5. Caldera R, Chavinie J, Fermanian J, Tortrat D, Laurent AM (1988). Maternal-fetal transfer of fluoride in pregnant women. Biol Neonate54(5), 263-269.

6. Callaghan J, Brown S, Battcock T, Parry S, Snook J. (2012). Aggressive Helicobacterpylori- negative peptic ulceration as the initial manifestation of Crohn's disease .Frontline Gastroenterol, 3(3), 201-205. 
7. Chlubek, D, Grucka-Mamczar, E, Birkner, E, Polaniak, R, Stawiarska-Pi囚ta, B, Duliban, H (2003). Activity of pancreatic antioxidativeenzymes and malondialdehyde concentrations in rats with hyper-glycemia caused by fuoride intoxication. J Trace Elem Med Bio, 17(1), 57-60.

8. Choudhary, S. and Mathur, P. (2020). Assessment of Protective Role of Quinoa against Sodium Fluoride Induced Skeletal Deformities in Mice Fetuses. Research Journal of Pharmacy and Technology, 13(5), 2129-2134.

9. Dharani, B., Sumathi, S., Sivaprabha, J. and Padma, P.R. (2011). In vitro antioxidant potential of prosopis cineraria leaves. Journal of Natural Product and Plant Resources, 1(3), 26-32.

10. EFSA (2005). Opinion of the scientific panel on dietetic products, nutrition and allergies on a request from the Commission related to the tolerable upper intake level of fluoride (Request No EFSA-Q-2003-018). EFSA J 192, 1-65.

11. Ekstrand, J, Alvan, G, Boreus, LO, Norlin, A (1977). Pharmacokinetics of fluoride in man after single and multiple oral doses. Eur J Clin Pharmacol,12(4), 311-317.

12. Elshama, S., Abdalla, M.E. and Mohamed, A.M. (2018). Role of Natural Antioxidants inTreatment of Toxicity. Journal of Analytical Toxicology, 1(3), 59-69.

13. Eshun, K. \& He, Q. (2004). Aloe vera: a valuable ingredient for the food, pharmaceutical and cosmetic industries-a review. Critical Reviews in Food Science and Nutrition, 44(5), 91-98.

14. Flora, SJS, Shrivastava, R and Mittal, M (2013). Chemistry and Pharmacological Properties of Some Natural and Synthetic Antioxidants for Heavy Metal Toxicity. Current Medicinal Chemistry, 20(36), 4540-4574.

15. Garcia-Montalvo, EA, Reyes-Perez, H, Del Razo, LM (2009). Fluoride exposure impairs glucose tolerance via decreased insulin expression and oxidative stress. Toxicology263(3), 75-83.

16. Godoy, D., Chokboribal, J., Pauwels, R., Banlunara, W., Sangvanich, P., Jaroenporn, S. and Thunyakitpisal, P. (2018). Acemannan increased bone surface, bone volume, and bone density in a calvarial defect model in skeletally-mature rats. Journal Of Dental Sciences, 13(1), 334-341.

17. Guth, S., Huser, S., Roth, A., Degen, G., Diel, P. and Edlund K. (2020). Toxicity of

fluoride: critical evaluation of evidence for human developmental neurotoxicity in epidemiological studies, animal experiments and in vitro analyses. Archives of Toxicology, 94(3), 1375-1415.

18. Gutknecht, J, Walter,A (1981).Hydrofuoric and nitric acid transport through lipid bilayer membranes. Biochim Biophys Acta, 644(1), $153-156$.

19. Hull, DH and Beale, PJ (1985). Cigarette smoking and duodenal ulcer. Gut., 26(12), 1333-7.

20. Hussein, H.H. and Mahmoud, O.M. (2013). Effects of maternal administration of aluminum chloride on the development of the skeletal system of albino rat fetuses - protective role of saffron. European Journal of Anatomy,17(2), 63-71.

21. Inamdar, I.F., Aswar, N.R., Sonkar, V.K. and Doibale, M.K. (2012). Drug utilization pattern during pregnancy. Indian Medical Gazette, $23(2), 305-311$.

22. Izquierdo-Vega, JA, Sanchez-Gutierrez, M, Del Razo, LM (2008). Decreased in vitro fertility in male rats exposed to fluoride-induced oxidative stress damage and mitochondrial transmem- brane potential loss. Toxicol Appl Pharmacol, 230(3), 352-357.

23. Jing, Li, Li Yao, A., Qing-Liang Shao, A., Chun-Yan Wuab, A. and Daqing (2004). Effects of high fluoride level on neonatal neurobehavioral development. Fluoride, 41(2), 165-170.

24. Lee, JH, Jung, JY, Jeong, YJ (2008). Involvement of both mitochondrial and death receptor- dependent apoptotic pathways regulated by Bcl-2 family in sodium fuoride-induced apoptosisof the human gingival fbroblasts. Toxicology, 243(3), 340-347.

25. Lee, YB, Yu, J, Choi, HH, Jeon, BS, Kim, HK and Kim, SW (2017). The association between

26. Madhusudhan, N., Basha M.P., Rai, P., Ahmed, F and Prasad R. G. (2009). Effect of maternal Fluoride exposure on developing CNS of Rats : Protective role of Aloe vera, Curcuma longa and Ocimum Sanctum. Indian Journal of Experimental Biology, 48(3), 830-836.

27. Madu, E. P., (2015). Teratogenic and embryotoxic effects of orally administered cypermethrin in pregnant albino rats. Journal of Toxicology and Environmental Health Sciences,7(7), 60-67.

28. Mendoza-Schulz, A, Solano-Agama, C, Arreola-Mendoza, L (2009). The effects of fluoride on cell migration, cell proliferation, and cell metabolism in GH4C1 pituitary tumour cells. Toxicol Lett, 190(2), 179-186.

29. Nada, A.S., Hawas, A.M., AbdElmageed, Z.Y. and Amin, N.E. (2013). Protective value of Aloe vera extract against girradiation induced some biochemical disorders in rats. Journal of Radiation Research and Applied Sciences, 6(1), 31-37.

30. Narayanaswamy, M. and Basha Piler, M. (2010). Effect of Maternal Exposure of Fluoride on Biometals and Oxidative Stress Parameters in Developing CNS of Rat. Biological Trace Element Research, 133(2), 71-82.

31. Niki, E., (2014). Fluoride and environmental health : A Review. Free Radical Biology and Medicine, 66(4), 3-12.

32. Osefo N, Ito T, Jensen RT (2009). Gastric acid hypersecretory states: recent insights and advances. Current gastroenterology reports, 11(6), $433-41$.

33. Perumal E., Paul, V.,Govindrajan, V.and Panneerselvam,L.(2013) A brief review on experimental fluorosis. Toxicology Letter,223(2), $236-251$.

34. Rauws, EAJ, Tytgat, GNJ (1990). Cure of duodenal ulcer associated with eradication of Helicobacter pylori. Lancet., 335(2): 1233-1235.

35. Sastry, BV (1999). Techniques to study human placental transport. Advanced Drug Delivery Reviews, 38(6), 17-39.

36. Shen, YW, Taves, DR (1974). Fluoride concentrations in the human placenta and maternal and cord blood. Am J ObstetGynecol, 119(2), $205-207$.

37. Singh, RH. (2000). Positive health potentials of Rasayan-Vajikaran therapy in Ayurveda. Ayurmedline, 2(3), 1-9.

38. Sun, Z., Zhang, Y., Xue, X., Niu, R. and Wang, J. (2018). Maternal fluoride exposure

during gestation and location decreased learning and memory ability of mouse pups. Human and Experimental Toxicology, 37(1), 87-93.

39. Vinson, J., Kharrat, A. H. \&Andreoli, L. (2005). Effect of Aloe vera preparations on the human bioavailability of vitamins C and E. Phytomedicine, 12(10), 760-769. 
40. Whitford, GM, Sampaio, FC, Pinto, CS, Maria, AG, Cardoso, VE, Buzalaf, MA (2008). Pharmacokinetics of ingested fluoride: lack of effect of chemical compound. Arch Oral Biol, 53(11), 1037-1041.

\section{Tables}

Table 1: Pre-natal observations in mice after administration of test substances ( $\mathrm{n}=8$ in each group)

\begin{tabular}{|c|c|c|c|c|c|c|c|c|}
\hline \multirow[t]{2}{*}{ Groups } & \multirow{2}{*}{$\begin{array}{l}\text { Average } \\
\text { no. of } \\
\text { corpora } \\
\text { lutea }\end{array}$} & \multirow{2}{*}{$\begin{array}{l}\text { Total no. } \\
\text { of implants } \\
\text { Average no. of } \\
\text { implants }\end{array}$} & $\begin{array}{l}\text { Total no. } \\
\text { of live } \\
\text { fetuses }\end{array}$ & \multirow{2}{*}{$\begin{array}{l}\text { Average body } \\
\text { weight of } \\
\text { fetus (g.) }\end{array}$} & $\begin{array}{l}\text { Total } \\
\text { resorptions }\end{array}$ & $\begin{array}{l}\text { Total immature } \\
\text { fetuses }\end{array}$ & $\begin{array}{l}\text { Total dead } \\
\text { fetuses }\end{array}$ & \multirow[t]{2}{*}{$\begin{array}{l}\text { Average } \\
\text { Placental } \\
\text { weight (g.) }\end{array}$} \\
\hline & & & $\begin{array}{l}\text { Average } \\
\text { no. of live } \\
\text { fetuses }\end{array}$ & & $\begin{array}{l}\text { Average } \\
\text { no. of } \\
\text { resorptions }\end{array}$ & $\begin{array}{l}\text { Average no. } \\
\text { of Immature } \\
\text { fetuses }\end{array}$ & $\begin{array}{l}\text { Average } \\
\text { no. of } \\
\text { dead fetuses }\end{array}$ & \\
\hline \multirow[b]{2}{*}{ Control } & \multirow[t]{2}{*}{$11.13 \pm 0.30$} & 77 & 77 & \multirow[t]{2}{*}{$1.16 \pm 0.04$} & 0.0 & 0.00 & 0.0 & \multirow[t]{2}{*}{$0.15 \pm 0.006$} \\
\hline & & $9.63 \pm 0.46$ & $9.63 \pm 0.46$ & & 0.0 & 0.00 & 0.0 & \\
\hline \multirow{2}{*}{$\begin{array}{l}\text { NaF, } 100 \\
\text { ppm }\end{array}$} & \multirow[t]{2}{*}{$11.25 \pm 0.41$} & 75 & 68 & \multirow[t]{2}{*}{$0.93 \pm 0.05$} & 0.0 & 5 & 7 & \multirow[t]{2}{*}{$0.14 \pm 0.008$} \\
\hline & & $9.13 \pm 0.64$ & $8.50 \pm 0.27$ & & 0.0 & $0.63 \pm 0.26^{*}$ & $0.88 \pm 0.40^{*}$ & \\
\hline \multirow{3}{*}{$\begin{array}{l}\mathrm{NaF}, 300 \\
\mathrm{ppm}\end{array}$} & \multirow[t]{2}{*}{$10.25 \pm 0.59$} & 67 & 53 & \multirow[t]{2}{*}{$0.716 \pm 0.054^{\star \star}$} & 2 & 8 & 12 & \multirow[t]{2}{*}{$0.15 \pm 0.01$} \\
\hline & & $8.38 \pm 0.75$ & $6.63 \pm 0.73^{* *}$ & & $0.25 \pm 0.25$ & $1.00 \pm 0.42^{\star \star}$ & $1.50 \pm 0.46^{\star \star}$ & \\
\hline & \multirow{3}{*}{$11.00 \pm 0.38$} & 70 & 67 & \multirow[t]{3}{*}{$1.01 \pm 0.035$} & 1 & 2 & 2 & \multirow[t]{3}{*}{$0.13 \pm 0.005$} \\
\hline $\mathrm{NaF}, 300$ & & & & & & & & \\
\hline $\begin{array}{l}\text { Ppm + } \\
\text { Aloe-vera }\end{array}$ & & $8.75 \pm 0.37$ & $8.38 \pm 0.37$ & & $0.13 \pm 0.13$ & $0.13 \pm 0.42$ & $0.25 \pm 0.16$ & \\
\hline
\end{tabular}

Values are mean $\pm S D ;{ }^{* * *} p<0.001,{ }^{* *} p<0.01,{ }^{*} p<0.05$ compared to control as evaluated by Student's 't' test using IBM SPSS statistics 22 software.

Table 2: Postnatal observations of various treatment groups at different days of the 21 days long weaning period in Swiss albino mice.

\begin{tabular}{|c|c|c|c|c|c|c|c|c|c|c|c|c|c|}
\hline & Day 1 & & & Day 4 & & & Day 7 & & & Day 14 & & & Day 21 \\
\hline Groups & $\begin{array}{l}\text { No. of } \\
\text { alive } \\
\text { pups }\end{array}$ & $\begin{array}{l}\text { Avg. } \\
\text { pup } \\
\text { weight } \\
\text { (Growth } \\
\text { index) }\end{array}$ & $\begin{array}{l}\text { Viability } \\
\text { index } \\
(\%)\end{array}$ & $\begin{array}{l}\text { No. of } \\
\text { Alive } \\
\text { pups }\end{array}$ & $\begin{array}{l}\text { Avg. } \\
\text { pup } \\
\text { weight } \\
\text { (Growth } \\
\text { index) }\end{array}$ & $\begin{array}{l}\text { Viability } \\
\text { index } \\
\text { (\%) }\end{array}$ & $\begin{array}{l}\text { No. of } \\
\text { alive } \\
\text { pups }\end{array}$ & $\begin{array}{l}\text { Avg. } \\
\text { pup } \\
\text { weight } \\
\text { (Growth } \\
\text { index) }\end{array}$ & $\begin{array}{l}\text { Viability } \\
\text { index } \\
\text { (\%) }\end{array}$ & $\begin{array}{l}\text { No. of } \\
\text { alive } \\
\text { pups }\end{array}$ & $\begin{array}{l}\text { Avg. } \\
\text { pup } \\
\text { weight } \\
\text { (Growth } \\
\text { index) }\end{array}$ & $\begin{array}{l}\text { Viability } \\
\text { index } \\
\text { (\%) }\end{array}$ & $\begin{array}{l}\text { No. of } \\
\text { Alive } \\
\text { pups }\end{array}$ \\
\hline & 8.40 & 1.55 & & $8.20 \pm$ & 2.56 & & 8.00 & 4.12 & & 7.80 & 6.16 & & 7.60 \\
\hline Control & \pm 0.51 & \pm 0.14 & 100 & 0.26 & \pm 0.20 & 97.61 & \pm 0.32 & \pm 0.26 & 95.23 & \pm 0.20 & \pm 0.14 & 92.85 & \pm 0.24 \\
\hline & & 1.70 & & 8.00 & 2.72 & & & 3.82 & & & 5.60 & & 7.20 \\
\hline $\begin{array}{l}\mathrm{NaF}, \\
100\end{array}$ & $\begin{array}{l}8.40 \pm 0 . \\
51\end{array}$ & \pm 0.05 & 100 & \pm 0.32 & \pm 0.12 & 95.23 & $\begin{array}{l}8.00 \pm 0 . \\
32\end{array}$ & \pm 0.22 & 95.23 & $\begin{array}{l}7.40 \pm 0 . \\
68\end{array}$ & \pm 0.30 & 88.09 & \pm 0.58 \\
\hline $\begin{array}{l}\mathrm{NaF}, \\
300\end{array}$ & $\begin{array}{l}7.00 \pm 0 . \\
45\end{array}$ & $\begin{array}{l}1.68 \\
\pm 0.05\end{array}$ & 100 & $\begin{array}{l}5.00 \\
\pm 0.55^{\star \star}\end{array}$ & $\begin{array}{l}2.48 \\
\pm 0.04\end{array}$ & 71.42 & $\begin{array}{l}4.60 \\
\pm 0.51^{\star \star} \\
\star\end{array}$ & $\begin{array}{l}3.44 \\
\pm 0.12\end{array}$ & 65.71 & $\begin{array}{l}4.40 \\
\pm 0.51^{\star \star} \\
\star\end{array}$ & $\begin{array}{l}4.60 \\
\pm 0.25^{\star} \\
\star\end{array}$ & 62.85 & $\begin{array}{l}3.60 \\
\pm 0.51 * \\
\star \star\end{array}$ \\
\hline $\begin{array}{l}\text { NaF, } \\
300+ \\
\text { Aloe- } \\
\text { vera }\end{array}$ & $\begin{array}{l}7.60 \\
\pm 0.51\end{array}$ & $\begin{array}{l}1.62 \\
\pm 0.11\end{array}$ & 100 & $\begin{array}{l}7.20 \pm 0 . \\
58\end{array}$ & $\begin{array}{l}2.44 \\
\pm 0.12\end{array}$ & 94.73 & $\begin{array}{l}7.00 \\
\pm 0.45\end{array}$ & $\begin{array}{l}3.66 \\
\pm 0.12\end{array}$ & 92.12 & $\begin{array}{l}6.80 \\
\pm 0.49\end{array}$ & $\begin{array}{l}4.90 \\
\pm 0.11 * \\
\star\end{array}$ & 89.47 & $\begin{array}{l}6.60 \\
\pm 0.60\end{array}$ \\
\hline
\end{tabular}

Values are mean $\pm S D ;{ }^{* \star} p<0.001,{ }^{* *} p<0.01,{ }^{*} p<0.05$ compared to control as evaluated by Student's ' $\mathrm{t}$ ' test using IBM SPSS statistics 22 software. 
Figures

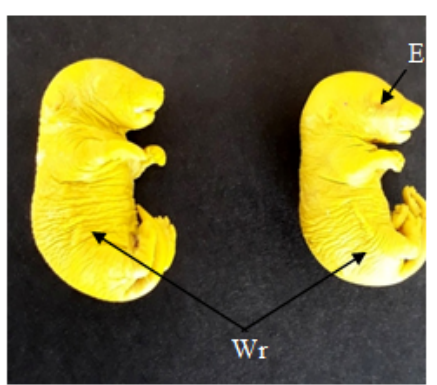

A

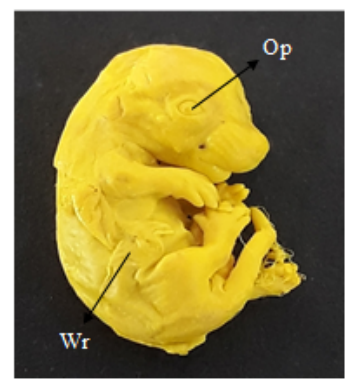

D

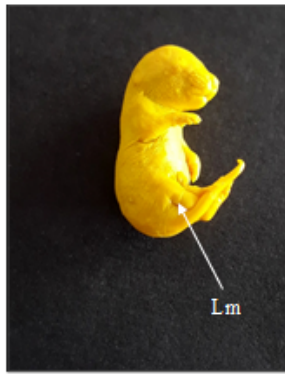

B

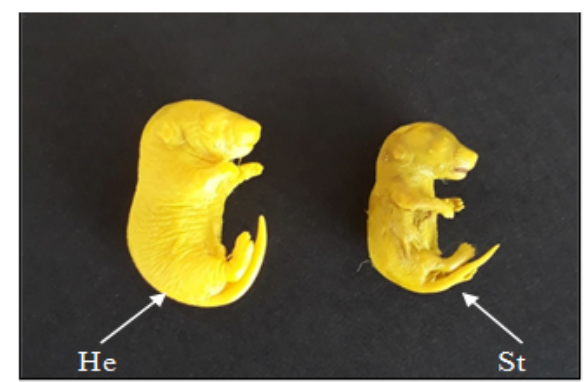

E(i and ii)

\section{Figure 1}

Figures showing fetuses of treated pregnant female mice on the 18th day of gestation after treatment with Sodium Fluoride (HD). (A) Wrinkles (Wr) on body and eye defect $(\mathrm{Ed})(\mathrm{B}, \mathrm{C})$ Limb defects $(\mathrm{Lm})$ in fetuses (D) Open eye (Op) and wrinkles on the whole body (Ei) Healthy fetus (He) of Sodium fluoride + Aloevera treated group (Eii) Stunted fetus (St) in Sodium fluoride (300 ppm) treated group

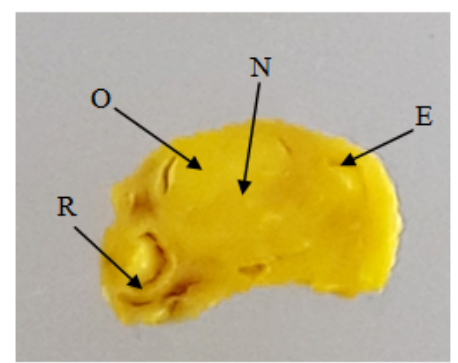

A

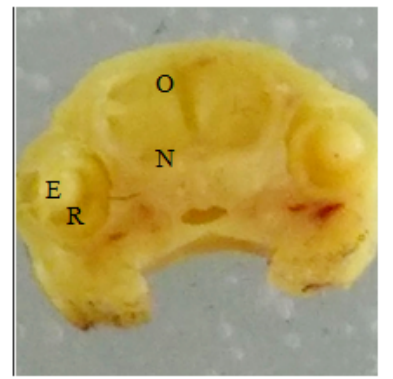

D

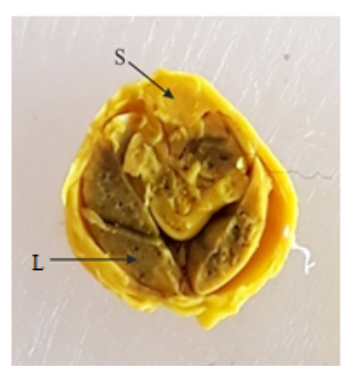

B

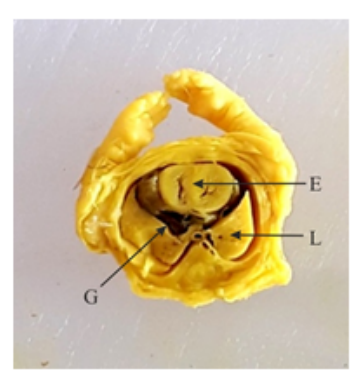

C

\section{Figure 2}

Free hand sections through head, thorax and abdominal regions of a fetus on the 18th day of gestation of Sodium Fluoride (HD) group showing (A) Anophthalmia (absence of eye) (B) Pulmonary edema (enlarged air spaces in lungs) (C) Enlarged esophagus (L - Lungs, E - esophagus, S - Spine, G - Gap) Free hand sections through head, thorax and abdominal regions of a fetus on the 18th day of gestation of Sodium Fluoride (300 ppm) + Aloe-vera treated group showing (D) Normal eye development (E and F) Normal lower and upper thoracic regions respectively showing $\mathrm{N}$ - Nasal cavity, $\mathrm{O}$ - Olfactory brain, $\mathrm{R}$ Retina, E - Eye 


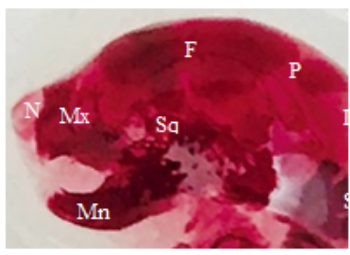

$\mathbf{A}$

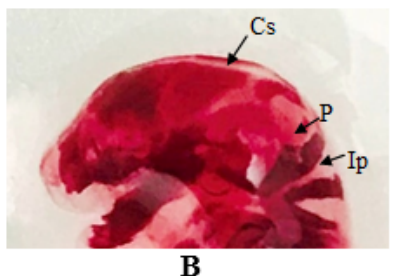

B

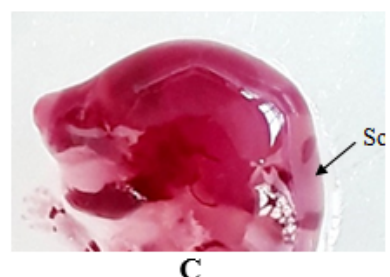

C

\section{Figure 3}

Figures showing lateral view of skull of fetuses on 18th day of gestation stained in alizarin red stain A. Complete ossification of frontal (F), parietal (P), interparental (Ip), supraoccipital (So), squamosal (Sq), maxilla (Mx), mandible (Mn), nasal (N) bones in control group. B. Craniofacial disorganization, reduced ossification of parietal, interparental and widened cranial sutures (Cs) in skull bones of Sodium Fluoride (300 ppm) treated group. C. Complete ossification of frontal (F), parietal (P) and other bones but reduced ossification of supraoccipital (So) bone in Sodium fluoride (300 ppm)+ Aloe-vera treated group.

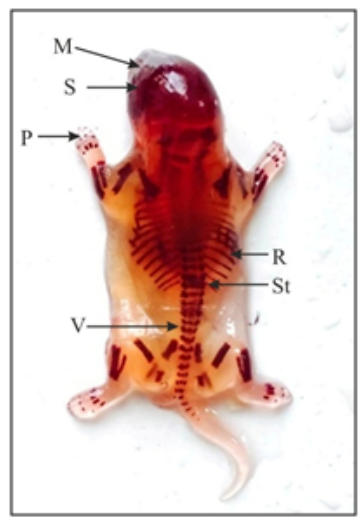

A

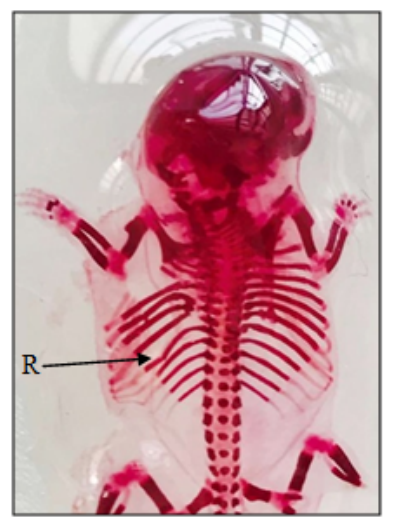

B

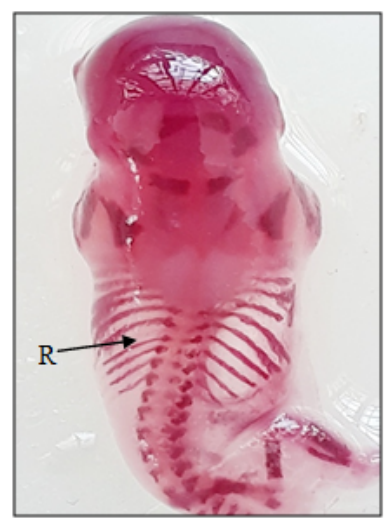

C

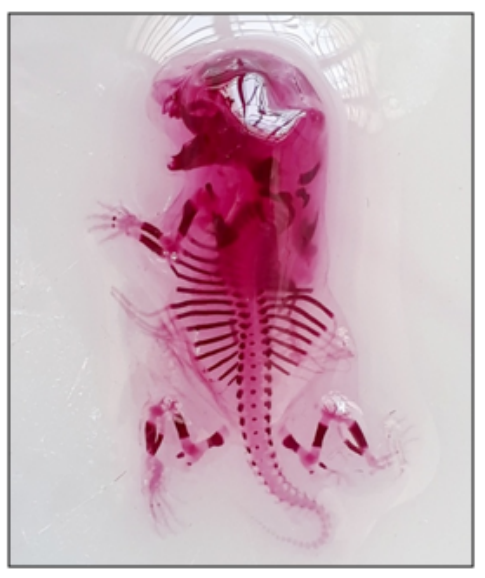

D

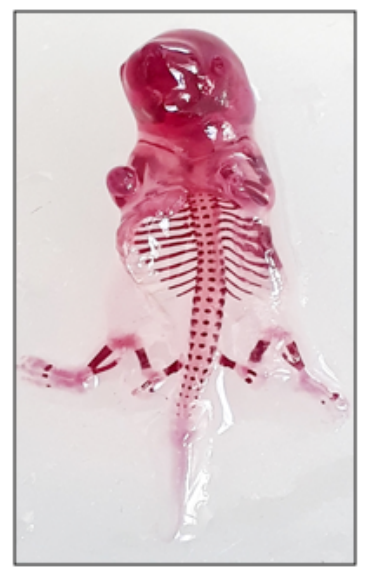

E

\section{Figure 4}

Figures showing whole body skeletal deformities (dorsal view) in fetuses (on 18th day of gestation) stained in alizarin red stain A. Complete ossification of mandible (M), skull (S), phalanges (P), ribs (R), sternum (St) and vertebrae (V) in control group. B. Wavy ribs and C. Widened rib gaps in Sodium fluoride (300 $\mathrm{ppm}$ ) treated group (D) Partial ossification of metacarpals (Mc) and metatarsals (Mt), poorly ossified Sterne brae(S), in Sodium fluoride (300 ppm) treated group. (E) Foetus (Ventral view) showing prominent wavy rib appearance but complete ossification of tibia, fibula, femur, metacarpals, metatarsals and stern brae in Sodium fluoride $(300 \mathrm{ppm})+$ Aloe vera treated group. 